\title{
SENSATIONALISM AND SOBRIETY \\ DIFFERENTIAL MEDIA EXPOSURE AND ATTITUDES TOWARD AMERICAN COURTS
}

\author{
CHRISTOPHER D. JOHNSTON* \\ BRANDON L. BARTELS
}

\begin{abstract}
While a great deal of research has focused on understanding the foundations of public support for American courts, scant attention has been paid to the role of the media for such attitudes. Given the media's demonstrated ability to influence public opinion, this remains a substantial gap in the literature. In the present paper we examine how different types of media — sensationalist (i.e., political radio and cable news) or sober (i.e., newspapers and network news) influence individuals' attitudes toward both the U.S. Supreme Court and courts at the state level. In line with our predictions, we find that sensationalist media exposure depresses both diffuse and specific support for American courts. Additionally, our results call into question the unconditional nature of the ubiquitous sophistication-approval relationship. We find that sophistication's positive effect on court attitudes is conditional on an individual's particular source of political information.
\end{abstract}

Myth sustains mystique, which shelters an institution from the public eye... But if the mask of myth falls, people can see more clearly what is going on. If an institution's involvement in raw political decision-making processes becomes visible, people may develop contempt for it. In contrast, invisibility and distance from the mass public sustain myth and thus legitimacy.

-Gregory Casey, 1974

The judicial branch holds a special place in the minds of citizens relative to the other institutions of American government. Research on public opinion of

CHRISTOPHER D. JOHNSTON is a Ph.D. candidate with the Department of Political Science, Stony Brook University, Stony Brook, NY, USA. BRANDON L. BARTELS is an assistant professor in the Department of Political Science, George Washington University, Washington, DC, USA. *Address correspondence to Christopher D. Johnston, Department of Political Science, Stony Brook University, Stony Brook, NY 11794-4392, USA; e-mail: johncd1@gmail.com. 
the U.S. Supreme Court, for instance, has consistently found high levels of support for the institution (e.g., Caldeira and Gibson 1992; Hibbing and Theiss-Morse 1995). From a normative perspective, this support is essential, as the judicial branch possesses neither appropriations nor enforcement powers; it thus relies on the goodwill of other branches and institutions, and the public more generally, to implement its rulings, and is relatively impotent absent such support (Caldeira 1986; Caldeira and Gibson 1992; Rosenberg 1991). These considerations have led to a wealth of research on the foundations of public opinion of the courts and the factors that lead to greater or lesser support for policy outputs, and general institutional approval (e.g. Benesh 2006; Caldeira 1986; Caldeira and Gibson 1992; Gibson, Caldeira, and Spence 2003a; Hoekstra 2000; Mondak 1990; Wenzel, Bowler, and Lanoue 2003).

Perhaps because of the low amounts of coverage the courts receive in the media, the public's view of these institutions has been characterized as mythological in nature and largely ignorant of the information necessary to make proper judgments about court processes and decision making (Casey 1974; Murphy and Tanenhaus 1968). From this perspective, the public is socialized early on to view the judicial branch in symbolic and legalistic terms, which leaves many with generally positive impressions (see Casey 1974; Tyler 1990). In addition, researchers have found that the more people know about the courts, the more positive their impressions of court procedures and outputs become, given that knowledgeable citizens receive greater exposure to the legitimating symbols with which the courts are associated (e.g., Casey 1974; Caldeira and Gibson 1992; Gibson, Caldeira, and Baird 1998). Thus, the judicial branch seems to benefit both from the scarcity of information regarding its inner workings and from the generally myth-supporting information that does filter down to the more knowledgeable individuals in the mass public. Consequently, the "reservoir of goodwill" that the courts enjoy shields them against sanctions from the public, even when specific decisions or policies may be largely unpopular (Caldeira and Gibson 1992; Gibson, Caldeira, and Spence 2003a).

While most national newspapers continue to provide rather sober coverage of the courts (and of the Supreme Court in particular), political talk radio and cable television shows have gravitated toward more sensationalist coverage and commentary of political institutions. These shows, which consist of "talking heads" and political pundits trading opinionated barbs, often depict institutions in a "no holds barred" style, and provide harsh, unbridled criticism of political (including court) decisions. Aside from direct attacks, the incivility of the discourse within these nontraditional media sources has the capacity to decrease political trust and delegitimize opposing viewpoints (Mutz 2007; Mutz and Reeves 2005).

To what extent does this sensationalist depiction constitute the bulk of what many citizens now associate with American courts? To paraphrase the quotation from Gregory Casey at the beginning of the article, have sensationalist 
media torn away the "mask of myth" that used to surround American courts (Casey 1974)? By shattering traditional mythologies, do these media-induced perceptions have deleterious consequences for perceptions and evaluations? We confront these questions through a cross-institutional lens with an examination of how exposure to sensationalist and sober media sources influences people's perceptions and assessments of not only the U.S. Supreme Court, but also state courts, which have received a fair share of criticism within sensationalist media. Analyzing data from two national surveys, we find that exposure to sensationalist media does indeed exhibit negative consequences for evaluative dimensions of the Supreme Court and state courts, whereas exposure to traditional, sober media sources exhibits positive effects on court evaluations. In addition, we examine the moderating effect of media exposure on the impact of sophistication, finding that the seemingly ubiquitous "to know courts is to love them" effect is actually conditional on the type of media to which one is exposed.

\section{American Courts and the Mass Media}

Although the public lacks a solid understanding of politics in general, it would be fair to say that people know much more about Congress and the presidency than they do about the U.S. Supreme Court and state courts (Delli Carpini and Keeter 1996). However, this lack of knowledge does not necessarily mean that a hollow foundation exists for evaluations of the judiciary. Throughout their lifetime people are socialized to subscribe to the myth of legalism and objectivity (Baird and Gangl 2006; Casey 1974). Combining myth with the public's general ignorance of the judiciary means that people associate courts with characteristics like procedural fairness, legalism, objectivity, and civility in decision-making processes (Casey 1974; Murphy and Tanenhaus 1968; Tyler 1984; Tyler and Rasinski 1991). Given the strong distaste citizens have for the conflicts and compromises intrinsic to the political process (Hibbing and Theiss-Morse 2002), the ability of the courts to shield their inner political workings, or "backstage" areas, from the public is an important factor in maintaining public support (Baird and Gangl 2006; Gibson 2008; Meyrowitz 1985; Scheb and Lyons 2000, 2001).

General ignorance of the inner workings of the courts can be partly attributed to the media's meager coverage of these institutions, leaving an informational void for most citizens (Slotnick and Segal 1998). Moreover, while we know that politics and ideological battles do occur in courts, the media may downplay these realities, leaving many people to fall back on the myths they develop about the courts earlier in life. However, this type of myth-supporting coverage is not universal, and may in fact be limited to print media and less opinionated sources such as network news programs. The content of "traditional" media sources, such as national newspapers, should be held to relatively higher journalistic standards, creating disincentives for sen- 
sational coverage of political institutions. On the other hand, "nontraditional" sources, such as entertainment talk shows, cable news programs, and political talk radio, are not bound to such standards to the same degree and are more concerned with entertainment value than restrained reporting.

Previous research on differences in coverage between traditional and nontraditional media outlets supports this expectation (e.g., Moy and Pfau 2000; Slotnick and Segal 1998; Spill and Oxley 2003). Indeed, Moy and Pfau (2000), in a content analysis of media genres in the mid-1990s, find that newspapers and other print media sources provided relatively benign coverage of political institutions, especially for the court system. In contrast, they note the "strikingly negative" coverage of institutions within nontraditional sources, with political talk radio tending to be the most critical (p. 81).

Slotnick and Segal (1998) find that television coverage of the Supreme Court is of a generally low quality, and that television reporters often mischaracterize decisions. Spill and Oxley (2003) find that the tone of the coverage of the Supreme Court differs based on media type. Specifically, print media such as daily newspapers tend to portray the Court in myth-supporting terms, focusing on the legal bases for judicial decision making. What these authors label as sensationalist media - political radio and cable television-tends to acknowledge the political nature of judicial decision making to a larger degree.

Few studies have focused on the link between coverage and attitudes within the context of the courts, however, and these studies have either been experimental (Baird and Gangl 2006; Clawson and Waltenburg 2003) or have only examined attitudes toward lower courts (Wenzel, Bowler, and Lanoue 2003), with conflicting results. In an experimental investigation, Baird and Gangl (2006) establish a causal link between the media framing of a Supreme Court decision in legalistic terms and perceptions of fairness in the decision-making process. Clawson and Waltenburg (2003) find that the media framing of affirmative-action decisions influences support for the decision among both Blacks and Whites. Examining actual survey data on state courts, Wenzel, Bowler, and Lanoue (2003) find no support for the contention that the media have any effect on diffuse or specific support for community courts. A closer examination of this issue using methods with greater generalizability is thus essential.

The possibility that different sources of information about the courts may offer competing views has interesting additional implications beyond the simple direct effects of this media consumption on perceptions and support. Research on public opinion toward the U.S. Supreme Court has consistently found a positive relationship between sophistication and diffuse support (Caldeira and Gibson 1992; Casey 1974; Gibson, Caldeira, and Baird 1998; Murphy and Tanenhaus 1968; Scheb and Lyons 2000). That is, "to know the Court is to love it." However, political sophisticates, while generally exposed to a greater amount of political information than non- 
sophisticates, may vary in the content of such exposure depending on a variety of factors both political and demographic. Thus, the positive effect of sophistication on attitudes found in prior research may be dampened by increasing exposure to sensationalist media. That is, as a result of exposure to "myth-busting" information, knowing more will not facilitate more positive attitudes, and may even foster negative attitudes toward American courts (Moy and Pfau 2000). When elite cues are not uniform, there is reason to suspect that the effects of political knowledge and sophistication will be conditional (Berinsky 2007; Zaller 1992).

\section{The Present Study}

We examine the effects of media exposure on two facets of court evaluation. Debates about evaluative orientations toward courts usually revolve around specific support (approval of court outputs) versus diffuse support (institutional legitimacy), and conceptual differences do indeed exist between the two (see Gibson, Caldeira, and Spence 2003b). Although approval is generally considered to tap specific support, Gibson, Caldeira, and Spence (2003b) have measured diffuse support of the Supreme Court with items tapping generalized trust, politicization (e.g., whether the Court is "too mixed up in politics"), and a willingness to reject fundamental alterations to the institution. The items capture the public's perceptions of institutional loyalty and legitimacy.

Our theoretical claim is that where an individual receives information about the courts will shape the way they think about the courts. Sensationalist media sources provide "myth-busting" information and commentary to a larger degree, and should thus break apart the foundations of court attitudes, leading to lower levels of diffuse and specific support. Sober media, on the other hand, generally focus on the legalistic nature of court processes, and should thus reinforce socialized, mythological views of the courts as above the political fray.

Distinct effects of media exposure as a function of attitude domain are also possible. Although we expect exposure to sensationalist sources to depress both diffuse and specific support, previous research on the Supreme Court suggests that diffuse support is a more enduring and less movable aspect of Court opinion (Caldeira and Gibson 1992; Gibson, Caldeira, and Spence 2003a), and thus it is reasonable to believe that the effect of media exposure should be greater for specific support. On the other hand, it is possible that the treatment of courts in the sensationalist media breaks apart the symbolic foundations of attitudes to an extent that both attitude domains are equally influenced. We examine these possibilities.

Our final expectation centers on the sophistication-evaluation link for the courts. Given that political sophisticates may gravitate to different sources of information, we examine how the choice of media moderates the positive effects of sophistication on attitudes (the "to know courts is to love them" 
effect). For individuals who gravitate to sensationalist media, we expect that sophistication will have a weakly positive, or possibly even negative, effect on attitudes. The marginal effects of sophistication for individuals who prefer sober media, in contrast, should be strongly positive.

\section{Data, Measurement, and Methods}

The data for our study come from two nationally representative surveys sponsored by the Annenberg Foundation Trust and directed by the Annenberg Public Policy Center at the University of Pennsylvania and Princeton Survey Research Associates International (PSRAI). For both surveys, interviews were conducted by PSRAI's sister company, Princeton Data Source, LLC. The first survey, the 2005 Annenberg Supreme Court Survey, interviewed 1,504 adults between March 17 and April 18, 2005, concerning their opinions of the U.S. Supreme Court. The second survey, the 2006 Annenberg Judicial Independence Survey, interviewed 1,002 adults between August 3 and August 16, 2006, regarding their opinions of the courts in the respondent's state of residence. ${ }^{1}$ Each survey also contains a battery of media consumption questions.

\section{MEASURING FACETS OF COURT EVALUATION}

All measures discussed here for the U.S. Supreme Court come from the 2005 Supreme Court Survey, and all measures for the state courts come from the 2006 Judicial Independence Survey. Exact question wording for all variables is included in Appendix A.

Diffuse support: For both the Supreme Court and Judicial Independence surveys, we utilize multiple items to create diffuse support scales in line with Gibson, Caldeira, and Spence (2003b). For the U.S. Supreme Court, respondents were asked to respond to several statements about the Court: the extent to which they agree that the Court (1) is politically motivated, (2) favors some groups over others, and (3) is too mixed up in politics; the extent to which the Court (4) can be trusted to operate in the public's best interests, and (5) can be trusted to make decisions that are right for the country; and finally, the extent to which they agree that (6) it would be better to do away with the Court

1. For both surveys, RDD telephone interviews were conducted. For the Supreme Court survey, the response rate was 41 percent. For the Judicial Independence Survey, the response rate was 26 percent. PSRAI's disposition codes are in accord with American Association for Public Opinion Research standards. PSRAI calculates the response rate as the product of three rates: the contact rate (proportion of working numbers where an interview request was made), the cooperation rate (proportion of contacted numbers who did not refuse an interview), and the completion rate (proportion of initially cooperating interviews that were completed). The data and additional information about the surveys can be downloaded from the Annenberg Public Policy Center Web site: www.annenbergpublicpolicycenter.org. 
altogether if it started making decisions that were highly unpopular. These items were combined into a summative scale reflecting diffuse support of the Supreme Court $(\alpha=.753)$. Before creating the scale, each item was recoded to range from 0 (low diffuse support) to 1 (high diffuse support). The diffuse support scale was then recoded from 0 to 1 as well, where higher values reflect greater diffuse support.

For state courts, respondents were asked to respond to a similar set of items: the extent to which they agree that their state courts are (1) too mixed up in politics, (2) legislating from the bench rather than interpreting the law, (3) politically motivated in their decision making, and (4) motivated by their own personal beliefs; the extent to which (5) the courts can be trusted to operate in the public's best interests, (6) the courts can be trusted to make decisions that are right for the country, and (7) the ethical practices of the state's judges are good; and finally, the extent to which they believe (8) it is important to be able to remove a judge from office on account of unpopular rulings. Using the same procedure as we did for the Supreme Court scale, each item was first recoded to range from 0 (low diffuse support) to 1 (high diffuse support). The items were then combined into a summative scale of diffuse support of the respondent's state courts $(\alpha=.683)$. The diffuse support scale was then recoded from 0 to 1 .

Specific support: Specific support is generally measured as overall approval of court performance and outputs. To measure approval for the Supreme Court, respondents were asked how they feel about the way the Supreme Court is handling its job. Four response categories were given, ranging from "doing a poor job" to "doing a very good job." No similar item was asked in the Judicial Independence Survey with state courts as the attitude objects. We are thus limited to estimating models of diffuse support in these latter analyses. Given the lesser salience of specific decisions within the state courts, we see this facet of court opinion as somewhat less relevant, and do not believe its absence to be overly concerning.

\section{MEASURING DIFFERENTIAL MEDIA EXPOSURE}

In measuring media exposure, we distinguish between sensationalist (political talk radio and cable news) and sober (newspapers and network news) sources. $^{2}$ We are interested in the degree to which a given individual is differentially exposed to one source relative to the other. Individuals who show a pattern of media exposure skewed toward sobriety should be more positive

2. The categorization of the media types in this manner will lead to some amount of error in measuring differential exposure. A few newspapers might fall under the category of sensationalist, as some talk radio might fall under the category of sober. We do not believe this substantially influences our results, and, if anything, should lead to more conservative tests of our hypotheses. 
in their evaluations due to the greater exposure to legitimating symbols and legalistic coverage contained therein. Conversely, individuals showing disproportionate exposure to sensationalist sources should be less positive given the emphasis within these sources on the ideological and partisan nature of decision making, and the vitriolic nature of discourse with respect to judges and judging generally.

In line with these considerations, we create a measure of differential media exposure from four items. The surveys ask respondents to indicate their level of exposure to newspapers ( $0-7$ days a week), cable news ( $0-7$ days), network news (0-7 days), and political talk radio. ${ }^{3}$ We calculate the measure as:

$$
\begin{aligned}
\text { Differencial media exposure }= & (\text { talk radio }+ \text { cable news }) \\
& -(\text { newspaper }+ \text { network news })
\end{aligned}
$$

Thus, the scale itself ranges from exclusively sober exposure (low values) to exclusively sensationalist exposure (high values). In essence, we are interested in how patterns of media consumption within individuals lead to more positive or negative attitudes toward American courts. The variable is recoded on a $0-1$ scale for ease of interpretation.

\section{MEASURING ADDITIONAL INDEPENDENT VARIABLES}

In both surveys, sophistication is measured via multi-item scales. Importantly, our sophistication measures tap domain-specific knowledge and awareness about the Supreme Court and state courts. In the Supreme Court survey, four questions ask about general knowledge of aspects of the Supreme Court (e.g., what a 5-4 ruling means). Additionally, the survey asks respondents to what degree they follow the rulings of the Court, and to what degree they understand the rulings of the Court. These six items were combined into a single sophistication scale $(\alpha=.606)$. The state courts survey asks similar questions, and four of these (three on general knowledge, one on subjective understanding) were combined into a single scale $(\alpha=.452)$.

We include the following demographic variables: age (measured in years), sex $($ male $=1$, female $=0$ ), race (whether or not respondent is Black or Hispanic, with White being the baseline group), and education (higher values reflect higher levels of education). We also include party identification as two dummy variables reflecting either Republican or Independent identification

3. For political talk radio, the measure differs across the two surveys. For the Judicial Independence Survey, radio exposure was measured identically to the other items ( $0-7$ days a week). For the Supreme Court Survey, however, respondents were asked to indicate their political talk radio exposure on a five-point scale ranging from "Never" to "Almost every day." 
(leaving Democratic identification as the baseline) ${ }^{4}$ and ideology (this variable was not asked in the Judicial Independence Survey; higher values are more conservative). Each variable was recoded on a 0 to 1 scale.

\section{THE ISSUE OF SELECTIVE MEDIA EXPOSURE}

Selective exposure- the notion that individuals are not simply exposed to a given media outlet at random but rather select into specific media types - has empirical implications for our ability to make inferences about the relationship between media coverage and court attitudes. We take two approaches to alleviating such concerns. First, if individuals who are less trusting toward institutions of American government generally are also more likely to choose sensationalist media outlets over sober ones (which is one form of selective exposure), then such generalized trust must be included in all models to avoid problems with endogeneity. For the Supreme Court survey, respondents were asked to indicate how much they generally trust the federal government to operate in the best interests of the people. There are four response options, and the variable was recoded to range from 0 to 1 . For the state courts survey, we use four variables to construct a political trust scale (there was no single generalized trust item within this survey). Two items ask about trust in Congress and the presidency, while the remaining items ask about the ethical practices of members of Congress and the president generally. The items were combined into a summative scale $(\alpha=.70)$, which ranges from 0 to 1 . These political trust items are included in all models.

Second, while we believe that controlling for these alternatives largely mitigates concerns with selective exposure, we additionally performed Hausman tests for all models as examinations of the endogeneity of differential exposure. Such tests assess whether the independent variable in question is correlated significantly with the error term of the model. We fail to reject the null hypothesis of exogeneity in all three models, indicating that differential exposure is not statistically endogenous in any of our models. Therefore, selective exposure does not pose a threat to the inferences we make below. Further details about these tests are included in Appendix B.

\section{Results}

We are interested in both the direct and the moderating impact of differential media exposure on attitudes toward both the Supreme Court and the state

4. Respondents were allowed to indicate whether they leaned Democrat or Republican even when they initially refused to answer the question. Given this measurement, we believe it is unclear what the categories of such an ordinal measure would truly represent. We thus use only the initial, nominal question asking Democrat, Republican, or Independent to maintain conceptual clarity. Three percent of individuals refused in the Supreme Court Survey, and 4 percent refused in the Judicial Independence Survey. These individuals were excluded from all analyses. 
courts. Given the coding of the differential exposure variable (with disproportionately sensationalist media exposure coded as high on the scale), we expect negative coefficients for exposure across all models. In addition, we predicted a moderating role for media exposure with respect to sophistication. Sophistication's unconditional effect would be expected to be positive based on past research. Thus, for each model, we expect the coefficient on the exposure by sophistication interaction term to be negative, indicating an attenuation or possible reversal of the effect of sophistication on court attitudes.

\section{SUPREME COURT MODELS}

The results for the Supreme Court models are shown in table 1. Ordinary least squares regression with robust standard errors was used for the diffuse support model, and ordered probit regression was used for specific support. Both noninteractive models (A and C) show support for the influence of media exposure on Court attitudes. Differential exposure has statistically significant, ${ }^{5}$ directionally appropriate, and substantively meaningful effects. For the diffuse support model, moving from high sober exposure to high sensationalist exposure predicts a decrease of about 10 points on the $0-1$ scale. To get a better sense of the impact of differential exposure on specific support, we generated predicted probabilities of approval using Clarify (Tomz, Wittenberg, and King 2001). We hold all interval-level control variables at their mean levels, race at "White," gender at "Female," and partisanship at "Democrat," and move differential exposure from its 5th (high sober exposure) to its 95th percentile (high sensationalist exposure). To ease interpretation, we collapse across the top two and bottom two categories of the dependent variable. The generated values can then be interpreted as the probability of approving of the job of the Supreme Court at each level of exposure, ceteris paribus. At high levels of sober exposure, the predicted probability of approval is about .431 . When we move to high levels of sensationalist exposure, this probability drops to about .347 , producing a change of -.084 in the probability of approval, or a decrease of slightly less than $20 \%$.

With respect to other variables, the models show results in line with expectations. First, the non-interactive models show that greater sophistication leads to an increase in both specific and diffuse support for the Court. This provides continuing support for the "to know the Court is to love it" effect. We also find males to be generally more positive than females toward the Court, and we find that education has a significantly positive effect as well. Blacks tend to have less positive diffuse support for the Court compared to Whites, which supports past work (Gibson and Caldeira 1992). The effect of the Republican dummy variable provides a comparison between Court attitudes of Republi- 
Table 1. Effects of Differential Media Exposure on Supreme Court Attitudes (standard errors in parentheses)

\begin{tabular}{|c|c|c|c|c|}
\hline \multirow[b]{3}{*}{ Variable } & \multicolumn{2}{|c|}{ Diffuse Support } & \multicolumn{2}{|c|}{ Specific Support } \\
\hline & (A) & (B) & (C) & (D) \\
\hline & Coef. & Coef. & Coef. & Coef. \\
\hline \multirow{2}{*}{$\begin{array}{l}\text { Differential Media } \\
\text { Exposure }\end{array}$} & $-0.10^{* *}$ & $-0.10^{* *}$ & $-0.34^{*}$ & -0.29 \\
\hline & $(0.03)$ & $(0.03)$ & $(0.17)$ & $(0.17)$ \\
\hline \multirow[t]{2}{*}{ Sophistication } & $0.18^{* *}$ & $0.18^{* *}$ & $0.60^{* *}$ & $0.61^{* *}$ \\
\hline & $(0.03)$ & $(0.03)$ & $(0.19)$ & $(0.19)$ \\
\hline \multirow{2}{*}{$\begin{array}{l}\text { Diff. Media Exp. x } \\
\text { Sophistication }\end{array}$} & - & -0.11 & - & $-1.92^{*}$ \\
\hline & & $(0.15)$ & & $(0.88)$ \\
\hline \multirow[t]{2}{*}{ Age } & -0.05 & -0.05 & $-0.62^{* *}$ & $-0.62^{* *}$ \\
\hline & $(0.03)$ & $(0.03)$ & $(0.16)$ & $(0.16)$ \\
\hline \multirow[t]{2}{*}{ Male } & $0.04^{* *}$ & $0.04^{* *}$ & $0.17^{* *}$ & $0.17^{* *}$ \\
\hline & $(0.01)$ & $(0.01)$ & $(0.06)$ & $(0.06)$ \\
\hline \multirow[t]{2}{*}{ Black } & $-0.05^{* *}$ & $-0.05^{* *}$ & -0.17 & -0.17 \\
\hline & $(0.02)$ & $(0.02)$ & $(0.11)$ & $(0.11)$ \\
\hline \multirow[t]{2}{*}{ Hispanic } & -0.01 & -0.01 & -0.08 & -0.08 \\
\hline & $(0.02)$ & $(0.02)$ & $(0.15)$ & $(0.14)$ \\
\hline \multirow[t]{2}{*}{ Education } & $0.09^{* *}$ & $0.09^{* *}$ & $0.32^{* *}$ & $0.31^{* *}$ \\
\hline & $(0.02)$ & $(0.02)$ & $(0.10)$ & $(0.10)$ \\
\hline \multirow[t]{2}{*}{ Republican } & 0.01 & 0.01 & 0.13 & 0.14 \\
\hline & $(0.02)$ & $(0.02)$ & $(0.09)$ & $(0.09)$ \\
\hline \multirow[t]{2}{*}{ Independent } & 0.01 & 0.01 & 0.01 & 0.02 \\
\hline & $(0.01)$ & $(0.01)$ & $(0.08)$ & $(0.08)$ \\
\hline \multirow[t]{2}{*}{ Ideology } & -0.04 & -0.04 & $-0.40^{* *}$ & $-0.38^{* *}$ \\
\hline & $(0.02)$ & $(0.02)$ & $(0.15)$ & $(0.15)$ \\
\hline \multirow[t]{2}{*}{ Political Trust } & $0.29^{* *}$ & $0.29^{* *}$ & $1.72^{* *}$ & $1.73^{* *}$ \\
\hline & $(0.02)$ & $(0.02)$ & $(0.13)$ & $(0.13)$ \\
\hline \multirow[t]{2}{*}{ Intercept } & $0.34^{* *}$ & $0.34^{* *}$ & - & - \\
\hline & $(0.02)$ & $(0.02)$ & & \\
\hline $\mathrm{N}$ & \multicolumn{2}{|c|}{1345} & \multicolumn{2}{|c|}{1301} \\
\hline Model & \multicolumn{2}{|c|}{ OLS } & \multicolumn{2}{|c|}{ Ordered Probit } \\
\hline Model $F / \chi^{2}$ & $34.25^{* *}$ & $31.59^{* *}$ & $220.81^{* *}$ & $231.69^{* *}$ \\
\hline$R^{2} /$ Pseudo $R^{2}$ & 0.21 & 0.21 & 0.09 & 0.10 \\
\hline
\end{tabular}

NotE. -Differential media exposure $=$ (frequency of talk radio exposure + frequency of cable news exposure) - (frequency of newspaper exposure + frequency of network news exposure); see text for more details.

$* p<.05$.

$*^{* *} p<.01$. 
cans and Democrats (since the latter is the excluded group). Interestingly, we see no statistically significant differences between Republicans and Democrats in evaluations of the Court. We do find that ideology exhibits a statistically significant effect on specific support and a marginally significant effect on diffuse support, but it is liberals who are more approving of the Court than conservatives. These results are in line with other research that finds, somewhat surprisingly, that liberals are more favorable than conservatives toward the contemporary conservative Supreme Court (Bartels and Johnston 2008; Hetherington and Smith 2007). Finally, we find that higher levels of political trust significantly increase evaluations of the Supreme Court across both models.

In addition to the unconditional effects for the Supreme Court models, we also examine the conditional effects of sophistication. In these interactive models ( $\mathrm{B}$ and $\mathrm{D}$ ), we mean-centered media exposure and sophistication, which means that the constituent effects for these two variables are conditional on the other variable held at its mean value. ${ }^{6}$ For the diffuse support model, the interaction is in the expected direction, yet statistically insignificant. However, additional calculations (via Brambor, Clark, and Golder 2006) show that, although the marginal effect of sophistication for someone with purely sensationalist exposure is statistically insignificant $(B=.12, p=.15)$, the marginal effect of sophistication conditional on purely sober exposure is nearly twice as large and statistically significant $(B=.23, p<.01)$. Thus, sensationalist media exposure dampens the "to know the Court is to love it" effect in a meaningful way.

For specific support, we find a large, statistically significant interaction effect. To more easily interpret the implications of this effect, we plot predicted probabilities of job approval (again collapsing across the top and bottom categories of the ordered dependent variable) against sophistication for three levels of differential exposure. We break this variable into high sober (5th percentile), mixed (mean level), and high sensationalist exposure (95th percentile). We can then interpret each plot as the marginal impact of sophistication on specific support for each level of exposure (holding all other variables at their means, gender at "Female," race at "White," and partisanship at "Democrat"). If we are correct in arguing that information source matters with respect to the effects of sophistication, then we should observe divergence of the lines for high sober and high sensationalist exposure within the graph. Looking at figure 1, for individuals characterized by disproportionately sober media exposure, increasing sophistication has a strong impact on approval of the Supreme Court, but for individuals who display more sensationalist patterns of consumption, sophistication has a null

6. Mean-centering does not alter the interaction effect itself. It simply eases interpretations of the constituent terms. 


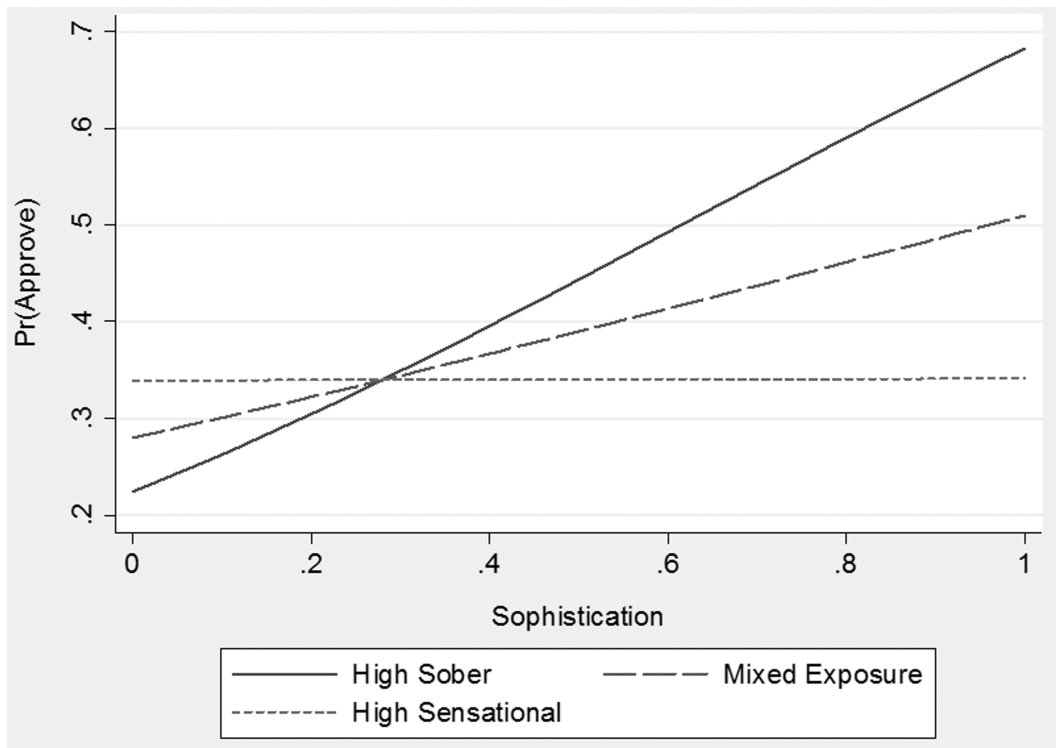

Figure 1. The Relationship Between Sophistication and Specific Support for the Supreme Court Conditional on Differential Media Exposure.

NOTE.-Lines are the predicted probabilities of approving of the job of the U.S. Supreme Court, across levels of sophistication, for different amounts of sensationalist media exposure. High sober exposure is defined as the 5th percentile of the differential exposure scale, high sensationalist is the 95th percentile, and mixed exposure is the mean value.

effect on specific support. Sophistication appears to have a marginally positive impact for individuals with mixed exposure patterns, again demonstrating the attenuating effect of sensationalist exposure for the impact of sophistication on specific support of the Supreme Court.

A second, simultaneously valid interpretation of these effects is also possible. Specifically, the plot indicates that the effects of differential exposure increase in magnitude as a function of sophistication; that is, the gap between the lines increases with increasing sophistication. Thus, the least sophisticated individuals are minimally responsive to the nature of the media outlet to which they attend, while high sophisticates appear to be highly susceptible. Such an interpretation is in accordance with sophisticates' greater ability to utilize information in political attitude formation (Berinsky 2007; Delli Carpini and Keeter 1996; Zaller 1992), and again provides evidence against treating individuals as homogenous with respect to this variable.

Discussion: In all, the Supreme Court models show evidence of the importance of media exposure for attitudes toward the Court. Across both 
dependent variables, we find that higher levels of exposure to sensationalist relative to sober media sources predict more negative attitudes toward the Court. Importantly, this effect is seen for both diffuse and specific support. In contrast to previous research on Supreme Court attitudes (e.g., Gibson, Caldeira, and Spence 2003a), we find diffuse support to be malleable, which has implications for the media's ability to sway individuals' perceptions of institutional legitimacy.

Additionally, the ubiquitous "to know the Court is to love it" effect is conditional on differential media exposure for specific support, though to a lesser extent for diffuse support. We find that, despite a general tendency for sophistication to be associated with more positive evaluations, it is critical to understand from where an individual's information about the Court is actually obtained. When such sophistication is associated with a pattern of media consumption confined to more sensationalist sources, the positive effect of sophistication on Court opinion is greatly attenuated. Sensationalist media exposure erases the "to know the Court is to love it" effect for specific support. Additionally, the interactive effect suggests that media exposure is more strongly associated with specific support for individuals who are more sophisticated.

\section{STATE COURTS MODELS}

The results for diffuse support of the respondent's state courts are shown in table 2 . The model is estimated using ordinary least squares with robust standard errors. In line with what was found for the Supreme Court, we find significant and substantively meaningful effects of differential media exposure. Beginning with the non-interactive model (A), moving from high sober to high sensationalist exposure is associated with about a nine-point decrease on the $0-1$ scale, an effect comparable to that for the Supreme Court diffuse support model.

Unlike in the Supreme Court models, sophistication does not exhibit a significant unconditional effect (though with $p=.12$, the effect is nontrivial). There is also suggestive evidence that Republicans exhibit lower diffuse support than Democrats, although this effect does not reach statistical significance. It is possible that this latter finding is an artifact of the exclusion of ideology from the state court models (which was itself absent from the Judicial Independence Survey), and we are picking up on this variance, which would be consistent with what was found for the Supreme Court. Finally, those more trusting in government generally show more diffuse support for the state courts, as would be expected.

Looking now at the interactive model (B), we again see a significant differential exposure by sophistication interaction in the correct direction. ${ }^{7}$

7. We mean-centered both media exposure and sophistication for the interactive model. 
Table 2. Effects of Differential Media Exposure on State Court Attitudes (standard errors in parentheses)

\begin{tabular}{|c|c|c|}
\hline \multirow[b]{3}{*}{ Variable } & \multicolumn{2}{|c|}{ Diffuse Support } \\
\hline & (A) & (B) \\
\hline & Coef. & Coef. \\
\hline Differential Media Exposure & $\begin{array}{l}-0.09^{* *} \\
(0.02)\end{array}$ & $\begin{array}{l}-0.09^{* *} \\
(0.02)\end{array}$ \\
\hline Sophistication & $\begin{array}{c}0.03 \\
(0.02)\end{array}$ & $\begin{array}{c}0.03 \\
(0.02)\end{array}$ \\
\hline $\begin{array}{l}\text { Diff. Media Exp. X } \\
\text { Sophistication }\end{array}$ & - & $\begin{array}{l}-0.23^{*} \\
(0.11)\end{array}$ \\
\hline Age & $\begin{array}{l}-0.02 \\
(0.02)\end{array}$ & $\begin{array}{l}-0.02 \\
(0.02)\end{array}$ \\
\hline Male & $\begin{array}{c}0.01 \\
(0.01)\end{array}$ & $\begin{array}{c}0.01 \\
(0.01)\end{array}$ \\
\hline Black & $\begin{array}{l}-0.02 \\
(0.01)\end{array}$ & $\begin{array}{l}-0.01 \\
(0.01)\end{array}$ \\
\hline Hispanic & $\begin{array}{l}-0.03 \\
(0.02)\end{array}$ & $\begin{array}{l}-0.03 \\
(0.02)\end{array}$ \\
\hline Education & $\begin{array}{l}0.05^{* *} \\
(0.02)\end{array}$ & $\begin{array}{l}0.05^{* *} \\
(0.02)\end{array}$ \\
\hline Republican & $\begin{array}{l}-0.02 \\
(0.01)\end{array}$ & $\begin{array}{l}-0.02 \\
(0.01)\end{array}$ \\
\hline Independent & $\begin{array}{l}-0.03^{* *} \\
(0.01)\end{array}$ & $\begin{array}{l}-0.03^{* *} \\
(0.01)\end{array}$ \\
\hline Political Trust & $\begin{array}{l}0.25^{* *} \\
(0.05)\end{array}$ & $\begin{array}{l}0.25^{* *} \\
(0.05)\end{array}$ \\
\hline Intercept & $\begin{array}{l}0.63^{* *} \\
(0.02)\end{array}$ & $\begin{array}{c}0.63^{* *} \\
(0.02)\end{array}$ \\
\hline $\mathrm{N}$ & & \\
\hline Model & & \\
\hline Model $F$ & $8.10^{* *}$ & $7.61^{* *}$ \\
\hline $\mathrm{R}^{2}$ & 0.10 & 0.11 \\
\hline
\end{tabular}

NOTE. - Differential media exposure $=$ (frequency of talk radio exposure + frequency of cable news exposure) - (frequency of newspaper exposure + frequency of network news exposure); see text for more details.

$$
\begin{aligned}
& * p<.05 . \\
& * * p<.01 .
\end{aligned}
$$

Similar to the Supreme Court analyses, we generate predicted values of diffuse support across levels of sophistication, and for three different levels of exposure within each model. We plot these results in figure 2. Looking at this 


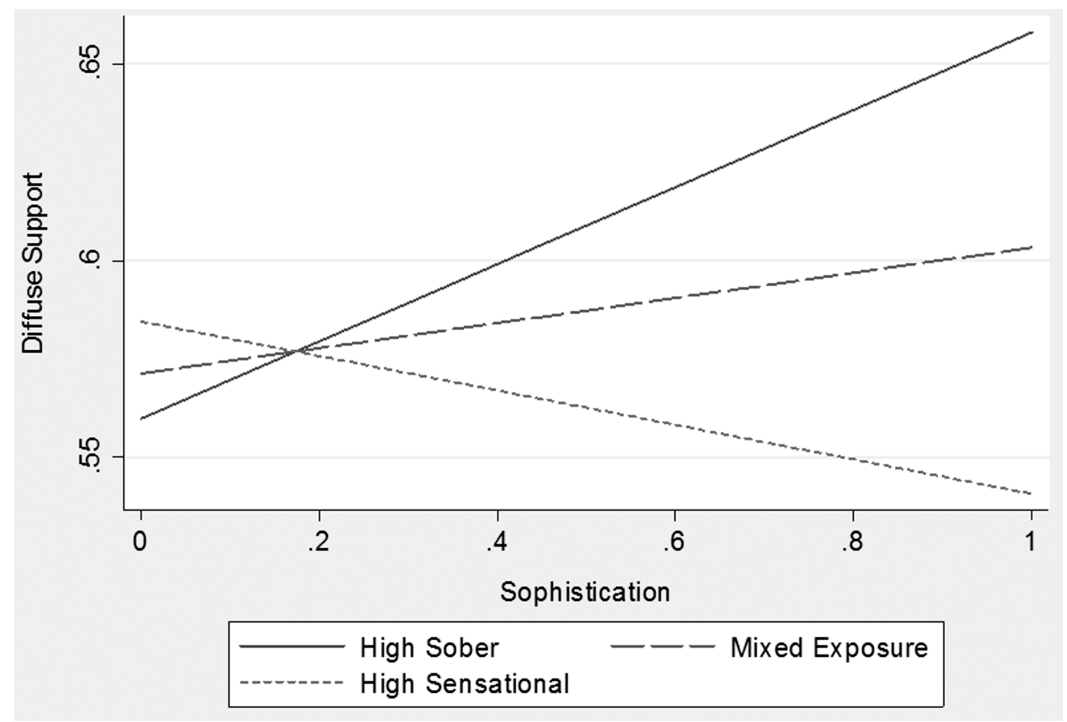

Figure 2. The Relationship Between Sophistication and Diffuse Support for State Courts Conditional on Differential Media Exposure.

NOTE.-Lines are the predicted values of diffuse support for the respondent's state courts, across levels of sophistication, for different amounts of sensationalist media exposure. High sober exposure is defined as the 5th percentile of the differential exposure scale, high sensationalist is the 95th percentile, and mixed exposure is the mean value.

figure, the pattern reinforces our findings from the Supreme Court models above. The estimated effect of sophistication is altered depending on one's pattern of media exposure. Among those who are exposed to high levels of sober media, sophistication leads to higher levels of diffuse support $(B=.098$, $p<.01)$. For mixed-exposure individuals, the effect is minimally positive ( $B=$ $.032, p<.06$ ). Among those exposed to high levels of sensationalist media, however, higher sophistication leads to lower levels of diffuse support (although the slope is not statistically significant; $B=-.044, p=.15$ ).

Once again, one may also interpret these interactions as the moderating effect of sophistication on the impact of differential exposure. From this perspective, it is clear that media exposure has its largest effect for high sophisticates.

Discussion: Complementing the findings of the Supreme Court models, the state court analyses support our hypotheses. High levels of sensational relative to sober media exposure predict decreased diffuse support. In addition, we find that such exposure also significantly moderates the impact of so- 
phistication. For individuals exposed to sober media sources, the "to know courts is to love them" hypothesis is supported. But for individuals exposed to sensationalist media, the opposite effect suggests itself: "to know courts is to dislike them." Thus, a complete understanding of the sophisticationevaluation relationship requires accounting for the type of information to which individuals are exposed. In addition, our second set of analyses is able to replicate the effects of media exposure across judicial institutions, increasing our confidence in the importance of the media for court attitudes generally.

\section{Conclusion}

The support of the general public is essential to the American court system, as judges possess neither powers of appropriation nor of sanction. Past research has argued that the high regard given to the courts as institutions is due to the socialization experienced by most of the general public to the symbols and myths of judging and the law more generally. Combining low average knowledge of "true" court processes with a reliance on a mostly uninterested media for information about ongoing court activities, a recipe for enduring loyalty and positive affect is generated. In this paper we paint a somewhat different picture of public opinion. Specifically, we argue that not all information concerning the courts is identical and, thus, where one gets their knowledge is determinative of their subsequent attitudes.

Past research has found little in the way of movement on measures of diffuse support for the courts, showing that approval may fluctuate somewhat as a function of specific decisions, but diffuse support is fairly, if not entirely, stable (see, however, Gibson 2008). In this paper we find that exposure to sensationalist media sources does indeed lead to substantially lower levels of both specific and diffuse support for both the Supreme Court and the state courts. The implications of these findings are critical to understanding the future course of public opinion of the courts. If these media continue on their current path toward greater sensationalism, derogating judges, highlighting political decision making, and emphasizing the bitterly partisan and ideological nature of the confirmation process, then we should expect deleterious consequences for opinion. The normative implications follow, in that declining public opinion empties the "reservoir of goodwill" that the courts have enjoyed and under certain conditions could lead to support for more fundamental changes to these institutions. Thus, a long-term dynamic element to diffuse support is introduced in our study.

Our cross-institutional comparison of the effects of media exposure on court attitudes also demonstrates that the effect sizes for the Supreme Court and the respondent's state courts are relatively equal. One might expect, given the greater propensity of sensationalist sources to attack lower-court judges directly (e.g., labeling them "activist") and highlight specific decisions dealing with emotionally charged issues, a larger effect of media exposure on 
lower-court attitudes. The fact that this does not appear to be the case raises some interesting questions for future research on the framing of judicial decision making in the mass media. In a public where information on the judiciary is generally scarce, do individuals rely to a large degree on the considerations they are able to bring to mind about "judges" generally? In other words, the portrayal of decision making on lower courts could have broad effects on public opinion of courts in general. An interesting path for future research, one limited by the data available here, would be to examine the extent to which such lower-court attacks "bubble up" to the level of the Supreme Court. If this is an accurate description of the process, some commentators may be exerting unintended influence over public opinion of a Supreme Court with which they may actually be in general ideological agreement. This could offer a possible explanation for the counterintuitive finding that, even with a more conservative Court, those on the ideological right in the mass public remain less approving, and skeptical, of the role of the Supreme Court in American society (Bartels and Johnston 2008; Hetherington and Smith 2007).

Additionally, the long-held belief in the literature of a positive impact of sophistication on court attitudes has been qualified by our findings. Sophistication matters and has a positive unconditional effect on both specific and diffuse support for the Supreme Court, though not for the state courts. The conditional effect of sophistication on both court systems, however, underlines the importance of accounting for where an individual has acquired the information leading to greater knowledge. In examining the marginal effects of sophistication as a function of information source, we are able to show how court sophisticates are far from being a homogenous bunch. Indeed, these results suggest the possibility that the impact of sophistication on attitudes can range from positive to negative. This is an important finding with respect to the Supreme Court's "reservoir of goodwill," given that political sophisticates are generally the most active participants in the political sphere. Declining long-term support among the opinion leaders of the public leaves the courts on shaky ground in terms of their protection from fundamental alterations in the face of negatively viewed decisions, and increases the difficulties associated with the implementation of policy (Rosenberg 1991).

The present study adds to the emerging literature on the role of media exposure for attitudes toward the judiciary in the United States. Although the few studies that have examined this topic to date have demonstrated a possible role for the media in court attitudes, replication with representative samples using methods with greater external validity is essential. The present study seeks to augment the literature both by accomplishing these goals and by adding a unique set of findings. At a minimum, these results strongly emphasize the importance of the media in the context of public opinion of the judiciary and promote greater consideration of the diversity of ways in which individuals come to know, but not necessarily love, American courts. 


\title{
Appendix A: Question Wording from Surveys
}

\section{Items from the 2005 Annenberg Supreme Court Survey}

\author{
DIFFUSE SUPPORT
}

(1) Which of the following statements comes closer to your beliefs about the Supreme Court? (1) The Court is fair and objective in its rulings; or (2) The Court is sometimes politically motivated in its rulings.

(2) Thinking about the current Supreme Court, please tell me if you strongly agree, somewhat agree, somewhat disagree, or strongly disagree with the following statement-The decisions of the Supreme Court favor some groups more than others.

(3) Thinking about the current Supreme Court, please tell me if you strongly agree, somewhat agree, somewhat disagree, or strongly disagree with the following statement-The Supreme Court gets too mixed up in politics.

(4) Generally speaking, how much do you trust the Supreme Court to operate in the best interests of the American people - a great deal, a fair amount, not too much, or not at all?

(5) Thinking about the current Supreme Court, please tell me if you strongly agree, somewhat agree, somewhat disagree, or strongly disagree with the following statement-The Supreme Court can usually be trusted to make decisions that are right for the country as a whole.

(6) Thinking about the current Supreme Court, please tell me if you agree or disagree with the following statement-If the Supreme Court started making a lot of rulings that most Americans disagreed with, it might be better to do away with the Court altogether. [four-point scale used]

\section{SPECIFIC SUPPORT}

(1) How do you feel about the way the Supreme Court is handling its job? Is it doing a very good, good, fair, or poor job?

\section{MEDIA EXPOSURE}

(1) Now I would like to ask about where you got your news during the past week. Please tell me how many days in the past week, if any, did you read a daily newspaper?

(2) Please tell me how many days in the past week, if any, did you watch national network news on TV-by which I mean Peter Jennings on ABC, Bob Schieffer on CBS, Brian Williams on NBC, or Jim Lehrer on PBS? 
(3) How often, if at all, do you listen to radio shows that invite listeners to call in to discuss current events, public issues, or politics-almost every day, every week, twice a month, once a month, or never?

(4) Now I would like to ask about where you got your news during the past week. Please tell me how many days in the past week, if any, did you watch cable news, such as CNN, Fox News Channel, or MSNBC?

\section{SOPHISTICATION}

(1) Do you happen to know who the current Supreme Court Chief Justice is?

(2) There are currently two Supreme Court Justices who are women. Do you know the names of either or both of these Justices?

(3) Can the U.S. Supreme Court declare an act of Congress unconstitutional or not?

(4) If the Supreme Court rules on a decision 5 to 4, does this mean the decision is final, the decision is too close and needs to be sent to Congress, or the decision is too close and needs to be sent back to the lower courts?

(5) How well do you feel you understand the Supreme Court's rulings-very well, somewhat well, somewhat poorly, or very poorly?

(6) And to what extent do you follow the decisions of the U.S. Supreme Court?

DEMOGRAPHICS, PARTY IDENTIFICATION, AND IDEOLOGY

Age: Respondents were asked how old they were (in years).

Race: The survey asked respondents' race or ethnicity. We coded whether people were White, Black, or Hispanic. Only 2 percent of the sample were of Asian descent.

Education: The survey asked the highest degree the respondent completed in school: (1) high school or less; (2) some college; (3) college graduate; (4) graduate coursework; or (5) graduate degree.

Party identification: "In politics today, would you consider yourself a Republican, Democrat, or Independent?" We operationalized this variable as a three-category nominal variable. Republican and Independent dummies are included, with Democrats serving as the baseline category.

Ideology: "In politics today, would you describe your views as very liberal, liberal, moderate, conservative, or very conservative?" We use a five-category scale, where higher values are more conservative.

Political trust: Generally speaking, how much do you trust the federal government as a whole to operate in the best interests of the American people - a great deal, a fair amount, not too much, or not at all? 


\title{
Items from the 2006 Judicial Independence Survey (for State Court Analysis)
}

\author{
DIFFUSE SUPPORT
}

(1) Turning to the court system in [state respondent lives in], please tell me if you strongly agree, somewhat agree, somewhat disagree, or strongly disagree with the following statement: The courts get too mixed up in politics.

(2) Turning to the court system in [state respondent lives in], please tell me if you strongly agree, somewhat agree, somewhat disagree, or strongly disagree with the following statement: The courts are legislating from the bench rather than interpreting the law.

(3) Which of the following statements comes closer to your beliefs about the courts in [state respondent lives in]? (1) The courts are fair and objective in their rulings; or (2) The courts are sometimes politically motivated in their rulings.

(4) In your opinion, to what extent do you think a judge's ruling is influenced by his or her personal political views - to a great extent, moderate extent, small extent, or not at all?

(5) Generally speaking, how much do you trust the courts in [state respondent lives in] to operate in the best interests of the American people-a great deal, a fair amount, not too much, or not at all?

(6) Turning to the court system in [state respondent lives in], please tell me if you strongly agree, somewhat agree, somewhat disagree, or strongly disagree with the following statement: The courts can usually be trusted to make rulings that are right for the state as a whole.

(7) Now, thinking about the ethical practices of judges in [state respondent lives in], in your opinion, are the ethical practices of judges in [state respondent lives in] very good, somewhat good, somewhat bad, or very bad?

(8) How important do you think it is to be able to impeach or remove a judge from office if the judge makes an unpopular ruling - essential, very important but not essential, somewhat important, or not too important?

\section{MEDIA EXPOSURE}

(1) How many days in the past week did you read a daily newspaper?

(2) How many days in the past week did you watch national network news on TV - by which I mean Bob Schieffer on CBS, Charles Gibson on $\mathrm{ABC}$, Brian Williams on NBC, or Jim Lehrer on PBS?

(3) How many days in the past week did you listen to talk radio shows that invite listeners to call in to discuss current events, public issues, 
or politics-for example, Rush Limbaugh, Don Imus, Al Franken, or Diane Rehm?

(4) How many days in the past week did you watch cable news, such as CNN, Fox News Channel, or MSNBC?

\section{SOPHISTICATION}

(1) Do you happen to know who the current Supreme Court Chief Justice is?

(2) To the best of your knowledge, do Supreme Court Justices usually give written reasons behind their rulings or do they NOT usually give written reasons?

(3) Do you happen to know any of the three branches of government? Would you mind naming any of them?

(4) How well do YOU feel you understand the purpose and role of the court system - very well, somewhat well, somewhat poorly, or very poorly?

\section{DEMOGRAPHICS, PARTY IDENTIFICATION, AND IDEOLOGY}

Age: Respondents were asked how old they were (in years).

Race: The survey asked respondents' race or ethnicity. We coded whether people were White, Black, or Hispanic. Only 2 percent of the sample were of Asian descent.

Education: The survey asked the highest degree the respondent completed in school: (1) high school or less; (2) some college; (3) college graduate; (4) graduate coursework; or (5) graduate degree.

Party identification: "In politics today, would you consider yourself a Republican, Democrat, or Independent?" We operationalized this variable as a three-category nominal variable. Republican and Independent dummies are included, with Democrats serving as the baseline category.

\section{POLITICAL TRUST}

(1) Generally speaking, how much do you trust Congress to operate in the best interests of the American people - a great deal, a fair amount, not too much, or not at all?

(2) Generally speaking, how much do you trust the president to operate in the best interests of the American people - a great deal, a fair amount, not too much, or not at all?

(3) Now, thinking about the ethical practices of members of Congress, in your opinion, are the ethical practices of members of Congress very good, somewhat good, somewhat bad, or very bad? 
(4) Now, thinking about the ethical practices of the president, in your opinion, are the ethical practices of the president very good, somewhat good, somewhat bad, or very bad?

\section{Appendix B: Details on Hausman Tests for Endogeneity of Differential Exposure}

While controlling for alternative explanations of the differential media exposure-attitudes relationship alleviates concerns with selective exposure to some degree, there remains the possibility that further excluded variables influence both exposure and the dependent variables of interest, thus inducing endogeneity and biasing model estimates. As in all survey-based research, controlling for all potential alternative explanations is simply not possible (as it is, theoretically speaking, in the experimental context); yet, the issue is important enough to our results that a statistical test of endogeneity seems warranted. To this end, we performed Hausman tests for all three models presented in the paper. Hausman tests assess whether an independent variable of interest is correlated with the error term of the relevant equation (i.e., it is endogenous). When this assumption is violated, all estimated coefficients in the equation will be biased, and the direction of such bias is generally unknowable.

The Hausman test procedure involves two basic steps. Consider the model below, where $y$ is the dependent variable of interest, $x$ is the independent variable whose exogeneity is in question, $z_{1}$ is a vector of exogenous variables (including the constant), and $u$ is the disturbance term.

$$
y=\beta_{1} x+\gamma_{1} z_{1}+u
$$

The first step of the Hausman procedure involves estimating a model of $x$ as a function of $z_{1}$ and a second vector $\left(z_{2}\right)$ of exogenous variables that are (a) proper exclusions from equation 1; and (b) explain a significant portion of the variance in $x$ above and beyond that of $z_{1}$ :

$$
x=\gamma_{1} z_{1}+\gamma_{2} z_{2}+v
$$

Because all exogenous variables are uncorrelated with $u$ by assumption, it follows that $x$ is endogenous in model 1 if and only if $\mathrm{E}(u v) \neq 0$. It can be shown that this will be the case when $\delta_{1} \neq 0$ in the following equation:

$$
y=\beta_{1} x+\gamma_{1} z_{1}+\delta_{1} v+e
$$

The second step, then, is to include the residuals from equation 2 in equation 1 as an estimate of $v$, and test for the significance of $\delta_{1}$ using a $t$-test 
(thus the null hypothesis of the test is exogeneity; see Wooldridge 2002, pp. 118-9, for further details).

For the Supreme Court models, we use six items for differential exposure: whether one reads blogs on the Internet, employment status, whether one goes online to get political information, whether one has cable in their household, whether one watches local news broadcasts, and reported income level. Employment status and income level represent proxies for the ability to subscribe to cable. Using the Internet to access political information is a proxy for a general propensity to seek out personally tailored news, a characteristic of sensationalist media. Finally, watching local news should be negatively associated with watching cable news, as individuals can access only one at a time. The same items were utilized for the state courts test, except for the blogs item, which was absent from the Judicial Independence Survey. These items accounted for 12 percent and 10 percent of the variance in differential exposure for the Supreme Court and state courts surveys, respectively. The estimated betas and standard errors for the residuals for the two Supreme Court models, diffuse and specific support, were .069(.151) $(p=.647)$, and $-.271(.847)(p=.749)$, respectively, indicating a lack of significance and thus a failure to reject the null hypothesis of exogeneity for differential exposure. Similarly, we fail to reject the null in the diffuse support model for the state courts $(B=-.054, S E=.089, p=.549)$.

\section{References}

Baird, Vanessa A., and Amy Gangl. 2006. "Shattering the Myth of Legality: The Impact of the Media's Framing of Supreme Court Procedures on Perceptions of Fairness." Political Psychology 27(4):597-614.

Bartels, Brandon L., and Christopher D. Johnston. 2008. Explaining Elite-Mass Differences in Evaluations of the U.S. Supreme Court. Paper presented at the Annual Meeting of the Midwest Political Science Association, Chicago, IL.

Benesh, Sara C. 2006. "Understanding Public Confidence in American Courts." Journal of Politics 68(3):697-707.

Berinsky, Adam J. 2007. "Assuming the Costs of War: Events, Elites, and American Public Support for Military Conflict.” Journal of Politics 69(4):975-97.

Brambor, Thomas, William R. Clark, and Matt Golder. 2006. "Understanding Interaction Models: Improving Empirical Analyses.” Political Analysis 14(1):63-82.

Caldeira, Gregory A. 1986. "Neither the Purse Nor the Sword: Dynamics of Public Confidence in the Supreme Court." American Political Science Review 80(4):1209-26.

Caldeira, Gregory A., and James L. Gibson. 1992. "The Etiology of Support for the Supreme Court." American Journal of Political Science 36(3):635-64.

Casey, Gregory. 1974. "The Supreme Court and Myth: An Empirical Investigation." Law and Society Review 8(3):385-420.

Clawson, Rosalee A., and Eric N. Waltenburg. 2003. "Support for a Supreme Court Affirmative Action Decision: A Story in Black and White." American Politics Research 31(3):251-79.

Delli, Carpini, X. Michael, and Scott Keeter. 1996. What Americans Know About Politics and Why It Matters. New Haven, CT: Yale University Press. 
Gibson, James L. 2008. "Challenges to the Impartiality of State Supreme Courts: Legitimacy Theory and 'New Style' Judicial Campaigns." The American Political Science Review 102(1):59-77.

Gibson, James L., and Gregory A. Caldeira. 1992. "Blacks and the United States Supreme Court: Models of Diffuse Support." Journal of Politics 54(4):1120-45.

Gibson, James L., Gregory A. Caldeira, and Vanessa A. Baird. 1998. "On the Legitimacy of National High Courts." The American Political Science Review 92(2):343-58.

Gibson, James L., Gregory A. Caldeira, and Lester K. Spence. 2003. "The Supreme Court and the U.S. Presidential Election of 2000: Wounds, Self-Inflicted or Otherwise? British Journal of Political Science 33:535-56.

Gibson, James L., Gregory A. Caldeira, and Lester K. Spence. 2003b. "Measuring Attitudes Toward the United States Supreme Court." American Journal of Political Science 47(2): $354-67$.

Hetherington, Marc J., and Joseph L. Smith. 2007. "Issue Preferences and Evaluations of the U.S. Supreme Court.” Public Opinion Quarterly 71(1):40-66.

Hibbing, John R., and Elizabeth Theiss-Morse. 1995. Congress as Public Enemy: Public Attitudes Towards American Political Institutions. New York: Cambridge University Press.

Hibbing, John R., and Elizabeth Theiss-Morse. 2002. Stealth Democracy: Americans' Beliefs About How Government Should Work. Cambridge: Cambridge University Press.

Hoekstra, Valerie J. 2000. "The Supreme Court and Local Public Opinion." The American Political Science Review 94(1):89-100.

Meyrowitz, Joshua. 1985. No Sense of Place: The Impact of Electronic Media on Social Behavior. New York: Oxford University Press.

Mondak, Jeffery J. 1990. "Perceived Legitimacy of Supreme Court Decisions: Three Functions of Source Credibility." Political Behavior 12(4):363-84.

Moy, Patricia, and Michael Pfau. 2000. With Malice Toward All? The Media and Public Confidence in Democratic Institutions. Westport, CT: Praeger.

Murphy, Walter F., and Joseph Tanenhaus. 1968. "Public Opinion and the United States Supreme Court: Mapping of Some Prerequisites for Court Legitimation of Regime Changes." Law and Society Review 2(3):357-84.

Mutz, Diana C. 2007. "Effects of 'In-Your-Face' Television Discourse on Perceptions of a Legitimate Opposition." American Political Science Review 101(4):621-35.

Mutz, Diana C., and Byron Reeves. 2005. "The New Videomalaise: Effects of Televised Incivility on Political Trust." The American Political Science Review 99(1):1-15.

Rosenberg, Gerald N. 1991. The Hollow Hope: Can Courts Bring About Social Change? Chicago, IL: University of Chicago Press.

Scheb, John M., and William Lyons. 2000. "The Myth of Legality and Public Evaluation of the Supreme Court.” Social Science Quarterly 81(4):928-40.

Scheb, John M., and William Lyons. 2001. "Judicial Behavior and Public Opinion: Popular Expectations Regarding the Factors That Influence Supreme Court Decisions." Political Behavior 23(2):181-94.

Slotnick, Elliot E., and Jennifer A. Segal. 1998. Television News and the Supreme Court: All the News That's Fit to Air? New York: Cambridge University Press.

Spill, Rorie L., and Zoe M. Oxley. 2003. "Philosopher Kings or Political Actors? How the Media Portray the Supreme Court." Judicature 87(1):22-9.

Tomz, Michael, Wittenberg Jason, and King Gary. 2001. Clarify: Software for Interpreting and Presenting Statistical Results. Version 2.0. Cambridge, MA: Harvard University, June 1. http:// gking.harvard.edu.

Tyler, Tom R. 1984. "The Role of Perceived Injustice in Defendants' Evaluations of Their Courtroom Experience." Law and Society Review 18(1):51-74.

Tyler, Tom R. 1990. Why People Obey the Law. New Haven, CT: Yale University Press. 
Tyler, Tom R., and Kenneth Rasinski. 1991. "Procedural Justice, Institutional Legitimacy, and the Acceptance of Unpopular U.S. Supreme Court Decisions: A Reply to Gibson." Law and Society Review 25(3):621-30.

Wenzel, James P., Shaun Bowler, and David J. Lanoue. 2003. "The Sources of Public Confidence in State Courts: Experiences and Institutions." American Politics Research 31(2):191-211.

Wooldridge, Jeffrey M. 2002. Econometric Analysis of Cross Section and Panel Data. Cambridge, MA: MIT Press.

Zaller, John R. 1992. The Nature and Origins of Mass Opinion. New York: Cambridge University Press. 